\title{
Partisipasi Masyarakat Dalam Mengembangkan Subak Lodtunduh Sebagai Daya Tarik Wisata Di Desa Singakerta, Kecamatan Ubud, Gianyar
}

Alif Rachman Nugrahaa,1, Ida Ayu Suryasiha,2

1alifrnugraha@gmail.com, 2idaayusuryasih@unud.ac.id

a Program Studi S1 Destinasi Pariwisata, Fakultas Pariwisata,Universitas Udayana, Jl. Dr. R. Goris, Denpasar, Bali 80232 Indonesia

\section{Abstract}

Subak is one of the Balinese cultural heritages, which has been assigned as one of World Cultural Heritage sites by UNESCO. Participation and empowering for local community is very important to occur equalization welfare and suistainable tourism ongoing on Subak Lodtunduh development as a tourist attraction. This research is very important for analyzing the local community participation to tourist attraction development in Subak Lodtunduh focused on development position of Subak Lodtunduh and their local community participation in various aspects. In this research methods used is qualitative research method. Qualitative method is used to reveal the form of local community participation. Qualitative and quantitative data in this research derived from primary and secondary data. Those collected by observation and literature review technique. Primary data explored by indepth interview to several informants that determined by purpossive sampling, then data annalyzed qualitatively to be explained in descriptive method. The result of this research is the form of community participation is limited to external parties such as the opinion by Tosun (1999). There are no real forms of the draft plan or detailed spatial Lodtunduh Subak rice cultivation to be a tourist attraction. The government's role was limited to initiate the Subak Lodtunduh to be more productive in the tourism sector in line with the agricultural sector that has been cultivated local communities Lodtunduh Subak communities.

Keywords: Community Participation, Subak Lodtunduh, Tourist Attraction

\section{PENDAHULUAN}

Subak ditetapkan oleh UNESCO sebagai Warisan Budaya Dunia pada 29 Juni 2012 dengan label Cultural Landscape of Bali Province: the Subak System as a Manifestation of the Tri Hita Karana Philosophy (Lanskap budaya Bali: Sistem Subak sebagai Manifestasi Filosofi Tri Hita Karana). Penetapan subak sebagai Warisan Budaya Dunia (WBD) menjadi kebanggaan masyarakat Bali khususnya, dan masyarakat Indonesia pada umumnya (Kemendikbud, 2013:7; Windia dan Wiguna, 2013:205).

Lebih lanjut Windia dan Wiguna (2013:32) mengatakan subak yang diperkirakan lahir pada abad ke-11 merupakan sebuah warisan masyarakat Bali yang memiliki nilai budaya yang sangat luar biasa. Melihat kenyataan tersebut, maka idealnya ada solusi yang dapat mensinergiskan pembangunan pariwisata dan pertanian, terlebih pada subak yang masuk dalam kawasan WBD Provinsi Bali. Sejalan dengan Perda Provinsi Bali No. 2 Tahun 2012 tentang Kepariwisataan Budaya Bali, bahwa sinergisme pembangunan sektor pariwisata dan pertanian sebagai sebuah budaya masyarakat Bali akan dapat memberikan kesejahteraan kepada masyarakat serta pelestarian budaya dan lingkungan.
Kegiatan pariwisata di Indonesia mendorong masyarakat untuk melakukan kegiatan partisipasi dalam mengembangkan suatu destinasi pariwisata. Partisipasi masyarakat dipandang sebagai suatu istilah yang dapat dibagi menjadi beberapa kategori, dimana berbagai kelompok yang berkepentingan ikut berpartisipasi dalam pembangunan pariwisata yang disesuaikan dengan kemampuan kelompok itu sendiri (Tosun, 2006).

Desa Singakerta yang berada pada ketinggian 200 meter diatas permukaan laut ini memiliki luas wilayah 765 ha. Bentuk Desa yang datar dengan temperatur minimum 27 Celcius dan curah hujan paling tinggi $2136 \mathrm{~mm}$ sehingga memungkinkan untuk melakukan kegiatan pertanian seperti padi, palawija dan holtikultura yang membujur dari utara ke selatan dan barat ke timur sehingga mayoritas penduduk Desa Singakerta berprofesi sebagai petani yaitu sebanyak 2100 orang (Data Statistik Desa Singakerta, 2007).

Untuk mewujudkan pembangunan pariwisata yang bermanfaat, bagi masyarakat luas, pemahaman aspek pembangunan pariwisata berbasis masyarakat (Community-Based Tourism Development) sangat penting artinya bagi masyarakat, karena masyarakat akan mempromosikan kesinambungan alam yang 
sangat berharga, aset yang memiliki nilai sejarah, lingkungan hidup yang nyaman, serta warna lokal (Natori, 2001: 4). Oleh karena itu, sangat menarik untuk menggali bagaimana partisipasi yang dilakukan oleh masyarakat lokal dalam mengembangkan Subak Lodtunduh sebagai daya tarik wisata di Desa Singakerta, Kecamatan Ubud, Gianyar.

\section{TINJAUAN PUSTAKA}

\section{1 Konsep Partisipasi Masyarakat}

Tosun (2006) mengklasifikasikan tipe-tipe partisipasi masyarakat ke dalam tiga tipe, yaitu:

1. Spontaneous participation; partisipasi yang dilakukan secara spontan.

2. Coercive participation; partisipasi yang dilakukan dengan cara kekerasan.

3. Induced participation; partisipasi yang dilakukan karena masyarakat terdorong untuk melakukannya.

Pretty (1995) mengemukakan mengenai tipologi partisipasi masyarakat (typology of community participation) yaitu:

1. Manipulative participation; adanya keterwakilan masyarakat dalam kelembagaan pariwisata, namun tidak memiliki kekuasaan.

2. Passive participation; masyarakat hanya diinformasikan hal yang sudah diputuskkan atau kejadian yang telah berlangsung.

3. Participation by consultation; masyarakat berpartisipasi dengan cara menjawab pertanyaan yang diajukan pihak eksternal.

4. Participation for material incentives; masyarakat memberikan sumberdaya dan kemudian mendapat kompensasi material.

5. Functional participation; pihak eksternal menginisiasi keterlibatan masyarakat dengan membentuk kelompok untuk menentukan tujuan bersama dan terlibat dalam pengambilan keputusan.

6. Interactive participation; masyarakat difasilitasi untuk membuat analisis, merumuskan program dan penguatan institusi lokal setempat.

7. Self-mobilization; masyarakat mempunyai inisiatif sendiri.

\section{2 Konsep Subak}

Menurut Peraturan Daerah Pemerintah Daerah Provinsi Bali Nomor 02/PD/DPRD/1972, subak adalah suatu masyarakat hukum adat yang memiliki karakteristik sosio-agraris-religius, yang merupakan perkumpulan petani yang mengelola air irigasi di lahan sawah.

Sedangkan menurut Arif memperluas pengertian karakteristik sosioagraris-religius dalam sistem irigasi subak, dengan menyatakan lebih tepat subak itu disebut berkarakteristik sosio-teknis-religius, karena pengertian teknis cakupannya menjadi lebih luas, termasuk diantaranya teknis pertanian, dan teknis irigasi.

\section{3 Konsep Daya Tarik Wisata}

Menurut UU No. 10 Tahun 2009 Tentang Kepariwisataan, pada Bab 1 Pasal 1 Ayat 5 memuat tentang pengertian daya tarik wisata adalah segala sesuatu yang memiliki keunikan, keindahan dan nilai yang berupa keanekaragaman kekayaan alam, budaya, dan hasil buatan manusia yang menjadi sasaran atau tujuan kunjungan wisatawan

Menurut Undang-Undang RI Nomor 9 Tahun 1990 Tentang Kepariwisataan Pasal 1 Ayat 6 memuat tentang pengertian obyek atau daya tarik wisata adalah segala sesuatu yang menjadi sasaran wisata.

\section{METODE PENELITIAN}

Lokasi penelitian ini berada di Subak Lodtunduh, Desa Singakerta, Kecamatan Ubud, Kabupaten Gianyar. Subak Lodtunduh terletak di sekitar area persawahan yang berhimpitan diantara jalan Desa Singakerta dan Jalan Raya Tebongkang.

Penelitian ini menggunakan teknik analisis deskriptif kualitatif. Teknik ini menganalisis potensi data berdasarkan pertimbanganpertimbangan keahlian dalam bentuk narasi. Ide maupun ungkapan yang ditemukan di lapangan diklarifikasikan dan dikategorikan berdasarkan berbagai tema sesuai dengan fokus penelitiannya (Hendarso dalam Madiun, 2010). Data dikumpulkan dari hasil observasi, wawancara mendalam, studi kepustakaan mengenai bentuk partisipasi masyarakat lokal dalam mengembangkan Subak Lodtunduh sebagai daya tarik wisata. Adapun teknik analisis data yang digunakan dalam penelitian ini adalah analisis data menurut Sugiyono (2009) yaitu proses mencari dan menyusun data yang diperoleh dari hasil wawancara, catatan lapangan, dan bahan-bahan lain secara sistematis sehingga mudah dipahami dan 
temuannya dapat diinformasikan kepada orang lain. Data yang dihimpun dari berbagai sumber akan diolah dan dianalisis untuk mengidentifikasikan partisipasi masyarakat di Subak Lodtunduh.

\section{HASIL DAN PEMBAHASAN}

\subsection{Gambaran Umum Lokasi Penelitian}

Desa Singakerta merupakan salah satu desa dari Kecamatan Ubud yang terletak paling ujung barat dari Kabupaten Gianyar dengan jarak sekitar 45 kilometer dari Kota Denpasar dan 20 kilometer dari kota Gianyar. Desa Singakerta terdiri dari 14 Banjar Dinas yang dikepalai oleh seorang Kelian Banjar Dinas, serta terdiri dari 5 Desa Pakraman (Desa Adat).

Batas-batas Desa Singakerta yaitu sebelah utara berbatasan dengan Desa Sayan, sebelah timur dengan Sungai Wos, sebelah barat dengan Sungai Ayung, dan sebelah selatan dengan Desa Singapadu Kaler.

Untuk menuju ke Desa Singakerta dari Denpasar, melewati akses jalan BatubulanKintamani. Pada saat menemui perempatan pom bensin Tebongkang, belok kiri menuju arah barat. Sepanjang jalan menuju ke Desa Singakerta sudah diaspal dengan baik, kendaraan dari segala penjuru dapat melewati jalan dengan bebas karena lebar jalan yang memungkinkan mobil untuk saling berpapasan dari arah yang berlawanan. Subak Lodtunduh di area persawahan yang berhimpitan diantara jalan Desa Singakerta dan Jalan Raya Tebongkang.

Berdasarkan data rekapitulasi jumlah penduduk Desa Singakerta tahun 2007, penduduk yang berdomisili di Desa Singakerta berjumlah 8793 jiwa merupakan campuran antara penduduk asli dan migran dengan jumlah kepala keluarga 1806 Kepala Keluarga (KK). Sementara itu jumlah penduduk banjar dinas Lodtunduh sejumlah 461 jiwa, 68 diantaranya merupakan anggota dari Subak Lodtunduh. Diketuai oleh seorang pekaseh subak bernama I Wayan Sutama. Seluruh anggota subak merupakan petani aktif yang masih melakukan kegiatan pertanian yang berlokasi di Subak Lodtunduh.

\subsection{Partisipasi Masyarakat Lokal dalam Mengembangkan Subak Lodtunduh Sebagai Daya Tarik Wisata}

Keindahan dan keelokan panorama sawah di Subak Lodtunduh memberikan kesempatan bagi masyarakat untuk ikut serta dalam mengembangkan sawah tersebut menjadi daya tarik wisata. Kekokohan petani dalam mempertahankan sawahnya dari arus globalisasi pariwisata yang selalu diisyaratkan sebagai tindakan alih fungsi lahan pertanian menjadi pariwisata membuat petani menjadi enggan menyerahkan lahannya semata-mata untuk pariwisata.

Banyaknya lahan yang menjadi bangunan yang mengalami peningkatan dari tahun ke tahun di Kecamatan Ubud membuat masyarakat petani Subak Lodtunduh tidak mempunyai pilihan lain lagi selain menjaga aset sawah yang dimilikinya. Peran pemerintah yang mendukung upaya Subak Lodtunduh, berpartisipasi aktif dalam memberikan bantuan yang bermanfaat bagi petani dan kelangsungan aktivitas pertanian. Untuk melangsungkan kedua aspek, pariwisata dan pertanian, maka persetujuan dan partisipasi masyarakat lokal mutlak diperlukan. Untuk menghindari konflik dari dampak pariwisata.

Dibalik kehidupan sederhana dan bersahaja dari anggota Subak Lodtunduh yang menjalani kehidupan hariannya dengan bertani di sawah, disadari atau tidak, terdapat bentuk partisipasi nyata yang dilakukan oleh masyarakat petani Subak Lodtunduh, sejak daya tarik wisata tersebut direncanakan, hingga telah adanya wisatawan yang berkunjung ke daya tarik wisata tersebut.

Penelitian tentang partisipasi masyarakat lokal dalam mengembangkan Subak Lodtunduh sebagai daya tarik wisata ini dengan metode atau pendekatan etik, sesuai dengan pendapat Liliweri (2004: 67), dimaksudkan bahwa, objek penelitian diselidiki dari sudut pandang sendiri atau pandangan dari "luar" pandangan sasaran penelitian. Peneliti memposisikan dirinya sebagai individu bebas yang berada di luar sasaran penelitian sebagai alasan untuk menghasilkan kesimpulan yang obyektif. Yang dimaksud bebas adalah dalam artian mempunyai kaidah ilmiah yang jelas, dapat dipertanggungjawabkan, konsep dan teori yang digunakan merupakan pendapat dari para pakar atau ahli, dan relevan dengan obyek yang diteliti.

Berbeda dengan metode atau pendekatan emik, menurut Liliweri (1994: 68) pendekatan 
emik mewajibkan peneliti untuk berada di "dalam" dan "hidup" dengan sasaran penelitian. Pendekatan ini memerlukan penguasaan yang mendalam bagi para peneliti ketika pendekatan ini diterapkan saat proses penelitian.

Dalam kaitannya dengan penelitian ini, informan penelitian diyakini betul telah memahami tentang secara utuh mengenai seluk-beluk objek penelitian. Harus diakui bahwa berbicara lebih lanjut mengenai bentuk partisipasi bukanlah pekerjaan yang mudah, dibutuhkan strategi penggalian secara utuh tentang bentuk, makna dan faktor-faktor yang mendorong masyarakat lokal dalam melakukan partisipasi dalam mengembangkan Subak Lodtunduh sebagai daya tarik wisata.

Diperlukan kombinasi secara komperehensif pendekatan etik dan emik mengenai bentuk, makna, dan faktor-faktor yang mendorong partisipasi masyarakat. Secara etik, diperlukan pemahaman teori dan konsep yang jelas, relevan, serta terkait erat dengan obyek penelitian, yakni partisipasi masyarakat. Disamping itu secara emik, diperlukan diskusi dan wawancara secara intensif dengan masyarakat lokal yang memang mengetahui dan terlibat langsung dalam proses pembangunan daya tarik wisata, ketika proses dan penggalian informasi tentang partisipasi masyarakat dilakukan (Madiun, 2010). Bentuk partisipasi masyarakat tersebut diuraikan menurut fase-fase yang dialami masyarakat lokal dalam mengembangkan daerahnya dalam paparan sebagai berikut.

\section{Kesadaran Masyarakat Akan Pariwisata}

Keberadaan suatu daerah yang kaya akan berbagai sumber daya namun masih bersifat potensial, tidak akan berpengaruh besar terhadap masyarakat lokal apabila masyarakat tersebut belum mempunyai kesadaran penuh dalam mengembangkan potensi yang ada. Menurut Soekanto (1993: 23) mengatakan bahwa "Manusia, masyarakat, dan kebudayaannya memang mempunyai kebudayaan-kebudayaan yang menakjubkan". Hal ini relevan dengan subak yang merupakan salah satu warisan budaya dunia mampu menjadi magnet bagi para calon wisatawan.

Oleh karena itu, pemikiran akan mengembangkan daerahnya khususnya untuk menjadi daya tarik wisata mutlak diperlukan masyarakat apabila ingin mendapatkan kehidupan yang lebih baik di masa depan. Sejalan dengan pendapat Koentjaraningrat (2002 : 36) "suatu bangsa yang hendak mengintensifkan usaha untuk pembangunan harus berusaha agar banyak dari warganya lebih menilai tinggi orientasi ke masa depan, dan demikian bersifat hemat untuk bisa lebih teliti memperhitungkan hidupnya di masa depan; lebih menilai tinggi orientasi ke arah archievement dari karya; dan akhirnya menilai tinggi mentalitas berusaha atas kemampuan sendiri, percaya pada diri sendiri, berdisiplin murni dan berani bertanggungjawab sendiri".

Sejak tahun 2013, Subak Lodtunduh sudah mulai kedatangan wisatawan baik lokal maupun mancanegara. Wisatawan yang datang biasanya melakukan kegiatan jalan kaki atau trekking mengitari sawah di Subak Lodtunduh. Hal ini ditengarai dengan indah dan eloknya sawah di Subak Lodtunduh yang terdengar hingga ke mancanegara. Keadaan akses jalan petak yang buruk (becek dan konstur tanah yang lembek) menghubungkan petak sawah satu dengan yang lainnya menyebabkan aksesibilitas wisatawan tidak berjalan dengan maksimal.

Melihat hal itu, pemerintah Kabupaten Gianyar menginisiasi Subak Lodtunduh untuk merencanakan merenovasi jalan setapak petak sawah dengan paving block dengan jarak 600 meter dari utara ke selatan dalam areal persawahan Subak Lodtunduh. Bahan bangunan yang dibuat untuk membangun jalan didapat dari bantuan pemerintah. Sedangkan tukang renovasi merupakan orang luar Subak Lodtunduh karena petani Subak Lodtunduh sibuk mengurusi lahan sawahnya.

Putu Yobi (22 Juni 2014), 60 tahun, salah seorang petani Subak Lodtunduh mengatakan:

“...kami sibuk setiap hari dari pagi sampai sore bekerja di sawah. Jika sudah jam 12 siang, kami beristirahat makan dan tidur, kemudian kembali ke sawah untuk bekerja jam 1 siang. Tidak sempat untuk mengurus membuat jalan petak. Biar pemerintah yang urus jalan itu".

Kesadaran petani akan memberikan sedikit lahan sawahnya untuk merenovasi jalannya agar memberikan kemudahan bagi para wisatawan yang berkunjung merupakan bentuk partisipasi masyarakat yang nyata. Hal ini sangat tinggi nilainya karena masyarakat sendiri yang memiliki aset namun memikirkan juga apabila wisatawan yang berkunjung mengalami peningkatan kunjungan di masa 
depan. Karena selama lahan tersedia, selama itulah peluang pembangunan dan pengembangan kawasan akan terus berjalan.

Bentuk partisipasi yang dilakukan oleh masyarakat ini sesuai dengan pendapat Tosun (1999) yaitu induced participation yang merupakan partisipasi karena ada dorongan, atau pendapat Pretty (1995) yang menyebutnya sebagai functional participation yang merupakan partisipasi fungsional karena ada peran faktor eksternal dalam menginisiasi keterlibatan Subak Lodtunduh untuk mengembangkan wilayahnya.

\section{Peningkatan Kualitas Sumber Daya Lokal}

Kehadiran wisatawan yang berkunjung ke suatu daya tarik wisata tentunya berpengaruh terhadap masyarakat lokal setempat. Berbagai macam aktivitas yang dilakukan wisatawan baik lokal maupun mancanegara baik secara langsung maupun tidak langsung memberikan arti yang signifikan bagi masyarakat. Berbagai potensi alam dan budaya yang dimiliki Subak Lodtunduh berangsur-angsur berubah menjadi atraksi wisata yang dapat dinikmati secara nyata oleh wisatawan.

Masyarakat yang awal mulanya hanya melakukan kegiatan yang bersifat tradisional, seperti beraktivitas di sawah, mulai tergerak untuk mengambil langkah-langkah baru untuk memanfaatkan potensi ekonomi yang ada sejak hadirnya wisatawan. Sebelum langkah bisnis pariwisata diterapkan, perlu adanya kualitas peningkatan sumber daya manusia khususnya pelatihan berkomunikasi dengan bahasa Inggris.

I Wayan Sutama, (18 Juni 2014), yang merupakan seorang pekaseh atau ketua Subak Lodtunduh mengatakan:

“...kami berharap pihak yang menaruh perhatian terhadap kami khususnya dalam hal pariwisata, memberikan kami sedikit pelatihan bahasa Inggris agar memudahkan kami berkomunikasi dengan turis asing. Setidaknya ada empat atau lima orang dari kami dikirim untuk mendapatkan les bahasa Inggris."

Walaupun masyarakat lokal telah berpuluhpuluh tahun tinggal di daya tarik wisata tersebut, belum ada jaminan mereka dapat menjelaskan secara rinci informasi mengenai daya tarik wisata tersebut. Oleh karena itu diperlukan peningkatan kualitas sumber daya lokal yang menjadi modal utama masyarakat lokal untuk mampu bersaing dengan pelaku wisata lainnya.

\section{Pariwisata Belum Menjadi Prioritas Masyarakat Lokal}

Sektor pertanian yang digeluti masyarakat petani Subak Lodtunduh selama berpuluhpuluh tahun menjadi zona nyaman yang tidak tergantikan. Adanya pariwisata yang berpotensi memberikan keuntungan yang besar seakanakan belum menjadi suatu wacana besar yang didengungkan di kalangan masyarakat Subak Lodtunduh. Masyarakat enggan untuk meninggalkan profesi sebagai petani hanya untuk menjadi pelaku wisata di daerahnya.

Menurut Qualter (dalam Edgar dan Sedgwick, 1999: 313), beberapa sifat wacana, diantaranya: merupakan kesengajaan dan bermaksud mempengaruhi orang-orang; propaganda mencoba untuk mempengaruhi perilaku dengan memodifikasi sikap, secara esensial dilakukan oleh kaum elit, dengan suatu kelompok kecil mencoba untuk mempengaruhi banyak orang; propaganda menggunakan banyak bentuk dan simbol (bahasa verbal, musik, maupun kesan yang dapat dilihat).

Putu Yobi (22 Juni 2014), mengatakan:

“...tahun 2014 ini sudah dua kali kami mengalami gagal panen padi, namun kami tetap mempertahankan sawah kami dan akan terus menjalankan aktivitas kami sebagai petani. Jika padi gagal, kami menanam tanaman bunga pacah, hasilnya lumayan untuk menghidupi keluarga jika sewaktu-waktu terjadi gagal panen padi."

Senada dengan I Wayan Sutama (18 Juni 2014), mengatakan:

"...saya di kala senggang menyisakan sawah untuk ditanami kangkung. Keuntungannya tidak sebesar padi tapi selalu habis karena dibeli pembeli. Mereka biasanya membeli kangkung untuk pakan ternak babi." Masyarakat dengan segala keterbatasan dan kepasrahannya terhadap ancaman gagal panen terus berusaha menjaga agar sawahnya terus berproduksi. Berbagai upaya dilakukan seperti menanam bunga pacah dan tanaman kangkung.

Namun, sudah ada wacana dari pemerintah Kabupaten Gianyar untuk mengembangkan Subak Lodtunduh untuk menjadi daya tarik wisata yang lebih besar lagi. Hal ini, sudah disampaikan kepada pekaseh Subak Lodtunduh.

I Wayan Sutama (18 Juni 2014), mengatakan

“...pemerintah sudah memberikan proposal (pengembangan Subak Lodtunduh) kepada kami. Namun kami belum memberikan perhatian secara serius terhadap hal ini. Kami hanya ingin fokus terhadap sawah kami dulu." 
Pihak Subak Lodtunduh terkesan membiarkan wisatawan yang datang untuk bebas melakukan aktivitasnya selama mereka berada di areal persawahan Subak Lodtunduh. Pihak Subak Lodtunduh merasa tidak terganggu dengan aktivitas wisatawan selama tidak menganggu petani dalam melakukan aktivitas pertaniannya.

Putu Yobi (22 Juni 2014), mengatakan.

“...meskipun jalanan sawah sering hancur akibat banyak turis datang, namun saya senang ada wisatawan yang datang. Saya menjadi tidak jenuh selama di sawah karena saya bisa melihat bagaimana orang luar (wisatawan) itu yang datang dari negara lain."

Senada dengan pekaseh Subak Lodtunduh yang membiarkan wisatawan yang datang tanpa melakukan pengembangan yang berarti.

I Wayan Sutama (18 Juni 2014), mengatakan:

“...biarkan dulu wisatawan banyak yang datang kesini, setelah banyak (wisatawan) yang datang, kami akan menentukan langkah-langkah apa yang dilakukan untuk menyelaraskan pertanian dan pariwisata dengan kebutuhan kami (masyarakat lokal)."

Keterangan yang diutarakan pekaseh Subak Lodtunduh terkesan ingin menghindari pariwisata yang bersifat konvensional. Seperti pendapat Natori (2001), bahwa konsep pembangunan pariwisata konvensional menunjukkan adanya ketidakseimbangan. Pembangunan pariwisata konvensional senantiasa memprioritaskan peningkatan jumlah pengunjung dengan mengabaikan atau kurang memberikan perhatian pada pertimbangan masyarakat lokal.

Bentuk partisipasi yang dilakukan oleh masyarakat ini sesuai dengan pendapat Tosun (1999) yaitu induced participation yang merupakan partisipasi karena ada dorongan, atau pendapat Pretty (1995) yang menyebutnya sebagai functional participation yang merupakan partisipasi fungsional karena ada peran faktor eksternal dalam menginisiasi keterlibatan Subak Lodtunduh untuk mengembangkan wilayahnya.

\section{Masyarakat Mendapatkan Keuntungan dari Aktivitas Wisata}

Mulai berkembangnya kegiatan pariwisata yang terjadi di Subak Lodtunduh menimbulkan berbagai dampak, khususnya dampak ekonomi yang dirasakan oleh masyarakat Subak Lodtunduh. Wisatawan yang berkunjung tidak secara langsung memberikan kontribusi berupa materi terhadap masyarakat lokal, melainkan pihak tour and travel atau pemandu wisata tersebut memberikan sedikit materi untuk diberikan kepada masyarakat lokal. Begitu pula dengan villa yang dibangun di area Subak tetangga, yaitu Subak Abiantiying, yang mengambil panorama dari sisi area persawahan Subak Lodtunduh.

Putu Yobi (22 Juni 2014), mengatakan:

“...kami (para petani) pernah diberi uang oleh tour and travel yang membawa tamu-tamu asing yang trekking dan foto-foto di sawah kami. Vila yang ada di depan subak kami itu juga pernah memberi uang, kami sangat berterimakasih terhadap pihak yang memberi uang kepada kami."

Masyarakat lokal pada akhirnya akan menikmati dampak khususnya dampak ekonomi dari segala upaya yang dilakukannya agar kehidupan masyarakat akan mengalami perubahan yang lebih baik di masa depan.

\section{SIMPULAN DAN SARAN}

\subsection{Simpulan}

Setelah melalui pembahasan dan analisis maka penelitian ini menyimpulkan beberapa pokok hasil penelitian, antara lain:

a. Bentuk partisipasi masyarakat hanya terbatas pada dorongan pihak eksternal seperti pendapat Tosun (1999), dan berupa partisipasi fungsional seperti pendapat Pretty (1995).

b. Belum ada bentuk nyata mengenai rencana atau rancangan detail tata ruang areal persawahan Subak Lodtunduh untuk menjadi daya tarik wisata.

c. Peran pemerintah hanya sebatas menginisiasi pihak Subak Lodtunduh agar lebih produktif di sektor pariwisata seiring dengan sektor pertanian yang selama ini digeluti masyarakat lokal masyarakat Subak Lodtunduh.

\subsection{Saran}

Berdasarkan hasil penjabaran mengenai bentuk partisipasi masyarakat dalam mengembangkan Subak Lodtunduh sebagai daya tarik wisata, maka dijabarkan beberapa saran antara lain sebagai berikut:

a. Pemerintah, penguasa, dan pengusaha harus melindungi masyarakat lokal dengan memberi dukungan penuh terhadap partisipasi yang dilakukan dalam mengembangkan wilayahnya. Apresiasi dibutuhkan masyarakat lokal agar tidak 
"malu-malu" dalam bergerak ke sektor lainnya, khususnya sektor pariwisata.

b. Masyarakat lokal harus diberikan porsi yang lebih besar dalam mengelola wilayahnya sendiri tanpa diintervensi dari pihak eksternal manapun. Hal ini karena masyarakat lokal adalah pemilik resmi asetaset yang dimilikinya.

c. Pendapatan daerah yang selama ini diperoleh pemerintah daerah hendaknya dialokasikan beberapa persen untuk memberikan pelatihan-pelatihan positif terhadap peningkatan kualitas sumber daya manusia, nilai jual produk, daya guna aset, dan daya saing para pelaku usaha yang bergerak didalamnya baik milik lokal maupun milik asing.

\section{Daftar Pustaka:}

Anonim. 1990. Undang-Undang RI Nomor 9 Tahun 1990 Tentang Kepariwisataan.

2009. Undang-Undang RI Nomor 10 Tahun 2009 Tentang Kepariwisataan.

Arif, S. 1999. Applying philosophy of tri hita karana in design and management of subak irrigation system, dalam a study of subak as indigenous cultural, social, and technological system to establish a culturally based integrated water resources management vol.III (ed: S.Susanto). Faculty of Agricultural Technology, Gadjah Mada University, Yogya.

Liliweri, Alo, 1994. Komunikasi Verbal dan Non Verbal. Bandung: PT. Citra Aditya Bakti.

$$
\text { 2004. Dasar-dasar Komunikasi Antar }
$$
Budaya. Yogyakarta: Pustaka Pelajar.

Madiun, Nyoman. 2010. Model Pengembangan Kawasan Wisata Modern. Denpasar: Udayana University Press.

Natori, Masahito. 2001. A Gudebook For Tourism Based Community. Development. Aptec Osaka-Japan.

Pemerintah Provinsi Bali. 1972. Peraturan Daerah Pemerintah Daerah Provinsi Bali Nomor 02/PD/DPRD/1972.

Pemerintah Provinsi Bali. 2012. Peraturan Daerah Provinsi Bali No. 2 Tahun 2012 tentang Kepariwisataan Budaya Bali.

Pretty, Jules N. 1995. Participatory Learning and Action; A Trainer's Guide. 267pp, ISBN:189825002, HED.

Soekanto, Soerjono. 1993. Beberapa Teori Sosiologi tentang Struktur Masyarakat. Jakarta: PT Raja Grafindo Persada.

Sugiyono. 2009. Metode Penelitian Bisnis (Pendekatan Kuantitatif, Kualitatif, dan R\&D). Bandung: Alfabeta.

Tosun, C. 2006. Expected Nature of Community Participation in Tourism Development. Turkey: School of Tourism and Hotel Management, Mustafa Kemal University, Tourism Management.

Windia dan Wiguna A.A. 2013. Subak Warisan Budaya Dunia. Denpasar: Udayana University Press. 